\title{
PENGATURAN KEWENANGAN JUDICIAL REVIEW TERHADAP PERDA OLEH MAHKAMAH AGUNG DAN PEMERINTAH
}

\author{
Alpatoni Saipul Anwar, \\ Sekretaris Organisasi Bantuan Hukum Kartini Tulungangung, Jawa Timur, \\ E-mail: alpatoni27@gmail.com, HP. 08563324463.
}

\begin{abstract}
ABSTRAKSI
Peraturan daerah merupakan produk legislatif daerah yang memerlukan perlakuan berbeda dengan peraturan non legislatif lainnya sehingga memerlukan lembaga lain untuk memberikan koreksi terhadap kesalahannya, yang memunculkan permasalahan siapa yang berwenang menguji Peraturan Daerah antara Mahkamah Agung atau Pemerintah, mengingat keduanya diberi wewenang yang sama oleh undang-undang. Penelitian ini mengkaji kewenangan menurut undang-undang tentang pemerintahan daerah dan judicial review Mahkamah Agung. Penelitian yuridis normatif dengan mengkaji undang-undang, teori-teori kewenangan, dan doktrin hukum dari para ahli hukum yang relevan dengan hal tersebut menemukan bahwa adanya dua peraturan yang memberikan kewenangan yang sama dalam hal pembatalan perda melalui Mahkamah Agung ataupun Pemerintah mengakibatkan adanya kerancuan hukum dan ketidakpastian hukum, sehingga perlu adanya pengaturan yang jelas sesuai dengan asas pemberlakuan peraturan perundang-undangan di Indonesia.
\end{abstract}

Kata kunci : Pengaturan kewenangan, Judicial Review, Peraturan Daerah

\section{PENDAHULUAN}

\section{Latar Belakang}

Sistem ketatanegaraan Republik Indonesia yang sebelumnya sentralistik atau terpusat pada eksekutif (pemerintah pusat) sebagai pemegang kekuasaan sentral dalam menentukan kebijakan publik dan penyelenggaraan negara. Namun, pasca perubahan Undang-Undang Dasar Negara Republik Indonesia (UUD 1945), sistem ketatanegaraan Indonesia bergeser mengarah ke sistem pemisahan kekuasaan (separation of power), antara cabang kekuasaan eksekutif, legislatif dan yudikatif yang memilikikewenangan saling mengawasi/kontrol (checks and balances syatem). ${ }^{1}$

Implikasi terhadap perubahan tersebut, melahirkan sistem penyelenggaraan Negara yang lebih demokratis, akuntabel dan transparan yang berdasarkan konstitusi. Hal tersebut ditegaskan dalam Pasal 1 ayat (3) UUD 1945 yang menyatakan bahwa "Negara Indonesia adalah Negara Hukum". Perubahan tersebut juga memperkuat sistem Negara Kesatuan Republik Indonesia (NKRI) berdasarkan Pancasila dan UUD 1945 yang diamanatkan dalam Pasal 18 ayat (1) UUD 1945 yang memuat ketentuan, Negara Kesatuan Republik Indonesia dibagi atas daerah-daerah provinsi dan daerah provinsi dibagi atas kabupaten dan kota, yang tiap-tiap provinsi, kabupaten, dan kota itu mempunyai pemerintahan daerah, yang diatur dengan undang-undang. Adanya prinsip mengatur dan mengurus sendiri urusan pemerintahan menurut asas otonomi dan tugas pembantuan, serta prinsip menjalankan otonomi seluasluasnya, kecuali urusan pemerintahan yang oleh undang-undang ditentukan

1Jimly Assyiddiqie, Pokok-Pokok Hukum Tata Negara Indonesia Pasca Reformasi, PT.Bhuana Ilmu Populer, Jakarta 2007, hlm. 590. 
sebagai urusan Pemerintah Pusat. Penegasan tersebut menjadi prinsip konstitusional bagi Pemerintahan Daerah dalam membentuk produk hukum daerah sebagai instrumen hukum dalam menjalankan system penyenggaraan daerah yang demokratis berdasarkan konsep Negara Kesatuan yang berdasarkan hukum. Oleh karena itu, keberadaan Peraturan Daerah dan peraturan pelaksanaan lainnya harus taat dan tunduk pada sistem hirarki peraturan perundang-undangan yang berlaku (Pasal 7 ayat (1) UU No. 12 Tahun 2011 tentang Pembentukan Peraturan Perundang -Undangan). Bertalian dengan itu, untuk mengendalikan norma hukum maka Pasal 24 A ayat (1) UUD 1945 berbunyi "Mahkamah Agung berwenang mengadili pada tingkat kasasi, menguji peraturan perundang-undangan di bawah undang-undang terhadap undang-undang, dan mempunyai kewenangan lainnya yang diberikan oleh undang-undang". Keberadaan kewenangan tersebut dapat dipahami bahwa Mahkamah Agung sebagai the judicial power yang merupakan bentuk pengawasan terhadap norma-norma hukum di bawah undang-undang terhadap undang-undang termasuk Peraturan Daerah dan Peraturan Kepala Daerah sebagai produk hukum daerah. Kewenangan Mahkamah Agung sebagai pelaku kekuasaan kehakiman merupakan kewenangan konstitusional yang diberikan oleh UUD 1945. Kewenangan pengujian peraturan perundang-undangan dibawah undang-undang terhadap undang-undang kemudian diatur lebih lanjut dalam Pasal 11 ayat (2) huruf b UU No. 4 Tahun 2004 tentang Kekuasaan Kehakiman, yang menyatakan bahwa, "Mahkamah Agung mempunyai kewenangan menguji peraturan perundang-undang di bawah undang-undang terhadap undang-undang". Pasal 11ayat (3) UU No. 4 Tahun 2004 tentang Kekuasaan Kehakiman berbunyi "Pernyataan tidak berlaku peraturan perundang-undangan sebagai hasil pengujian sebagaimana pada ayat 2 Huruf $b$ dapat diambil dalam pemeriksaan tingkat kasasi maupun berdasarkan permohonan langsung kepada Mahkamah Agung". Kewenangan Mahkamah Agung untuk menguji produk hukum di bawah undang-undang kemudian dikenal dengan istilah "Judicial Review".

Peraturan Daerah atau sering disingkat PERDA adalah instrument hukum terendah dalam hierarki peraturan perundang-ndangan. Proses pembentukan perda yang dilakukan oleh pemerintah daerah dengan DPRD secara bersama tentunya telah memenuhi kualifikasi sebagai peraturan ditingkat daerah yang legal menurut konstitusi kita.

Perubahan peradaban manusia dari masa ke masa yang tidak dapat dihindari seringkali menjadikan peradaban hukum juga mengalami ketertinggalan yang teramat jauh, sehingga adanya perubahan peraturan dan penyesuaian dengan kondisi sosial masyarakat dijamanya harus senantiasa dilakukan, agar hukum mampu menjawab tantangan jaman sehingga keteraturan kehidupan berbangsa dan bernegara bisa senantiasa terjaga. Suatu pendekatan lain terhadap arti hukum dilakukan dengan menelaah fungsi yang harus dipenuhi oleh hukum. E. Adamson Hobel dan Karl Llewellyn menyatakan, bahwa hukum mempunyai fungsi yang penting demi keutuhan masyarakat.

1. Menentukan hubungan antara masyarakat, dengan menentukan perikelakuan mana yang diperbolehkan dan mana yang dilarang; 
2. Membuat alokasi wewenang (authority) dan menentukan dengan seksama pihak-pihak yang secara sah melakukan paksaan dengan sekaligus memilih sanksi-sanksi yang tepat dan efektif ;

3. Disposisi masalah-masalah sengketa;

4. Menyesuaikan pola-pola hubungan dengan perubahan kondisi kehidupan. ${ }^{2}$

Di dalam pasal 7 ayat 1 UU No. 12 Tahun 2011 tentang Pembentukan Peraturan Perundang -Undangan jenis dan peraturan perundang-undangan adalah sebagai berikut.

1. Undang-undang Negara Republik Indonesia tahun 1945

2. Undang-undang/PERPU

3. Peraturan Pemerintah

4. Peraturan Presiden

5. Peraturan Daerah

Dengan demikian perda merupakan peraturan terendah dalam hierarki peraturan perudang-undangan di Negara kita, yang tidak boleh bertolak belakang dengan peraturan diatasnya, sehingga dalam muatan peraturan perundang-udangan haya memuat hal-hal yang belum tercover oleh peraturan diatasnya. Menurut Hans Kelsen dalam teori Stefenbau Dest Recht bahwa hukum positif (peraturan) diberlakukan berjenjang dan berlapis-lapis peraturan yang rendah bersumber dari dan tidak boleh bertentangan dengan peraturan yang lebih tinggi. ${ }^{3}$ yang dalam ilmu hukum disebutdengan asas Lex Superior Derogat lex inferior.

Pengujian perda terhadap peraturan perundang-undangan yang lebih tinggi dapat dilakukan oleh Mahkamah Agung (Judicial Review) sebagaiamana diatur dalam pasal 24A ayat (1) perubahan ke tiga UUD 1945. ${ }^{4}$ Kemudian pasal 11 ayat 2 huru b undang-undang No 4 tahun 2004 Tentang Kekuasaan Kehakiman. ${ }^{5}$ Selanjutnya pada pasal 31 ayat 2 udangundang No 5 tahun 2004 tentang Mahkamah Agung. ${ }^{6}$ Undang -undng tersebut memberikan ukuran dalam hal apa Mahkamah Agung dapat menguji sebuah perda yaitu dalam hal bertentangan dengan undang-undang yang lebih tiggi secara muatan atau isinya (materil) dan dari segi proses pembentukanya (formil), dalam menguji perda mahkamah agung bersifat pasif.

Judicial review merupakan hak menguji (toetsingrecht) dari kekuasaan yudikatif untuk melakukan pengujian terhadap peraturan perundang-undangan. Fungsi judicial power dalam melakukan pengujian ini didasarkan pada kewenangan pengawasan sebagai konsekuensi dari prinsip check and balance antar organ pelaksana kekuasaan negara. Alexander Hamilton merupakan pemikir pertama yang memberikan pemikirannya tentang judicial review yang

\footnotetext{
2 Sarjono sukanto, I . Pokok-Pokok Sosiologi Hukum. Jakarta: Raja Grafindo Persada, 2012. Hlm. 74

3 Teori Hans Kelsen tentang Hukum. Www jimly.com. diakses tanggal 2 Oktober 2016

4 Pasal 24A Undang-Undang Dasar 1945.

${ }^{5}$ Pasal 11 ayat 2 huruf b Undang-Undang No 4 Tahun 2004 Tentang Kekuasaan Kehakiman.

6 Pasal 31 ayat 2 Undang-Undang No. 5 Tahun 2004 tentang Mahkamah Agung.
} 
dimuat di surat kabar Federalis Edisi Nomor 78. Pendapat Alexander Hamilton tersebut yang memberikan landasan pemikiran dan mendorong Supreme Court. ${ }^{7}$

Kewenangan menguji perda berikutnya melalui lembaga eksekutif (eksekutive review) sebagaimana diatur dalam undag-undang Nomor 32 tahun 2004 pasal 145 ayat 2 yang diperbaharui dengan UU No 23 Tahun 2014 meyebutkan perda yang bertentangan dengan ketertiban umumdan atau peraturan perundang-undangan yang lebih tinggi dapat dibatalkan oleh pemerintah. Pada ayat 3 disebutkan keputusan pembatalan perda di ditetapkan dengan peraturan presiden paling lama 60 hari sejak diterimanya perda. Dan ayat 5 menyebutkan apabila provinsi/kabupaten /kota tidak dapat menerima pembatalan perda dengan alasan yang dapat dibenarkan peraturan perundang-undangan, kepala daerah dapat mengajukan keberatan pada Mahkamah Agung.

Dari munculnya satu kewenangan yang sama dalam dua lembaga yang berbeda itulah yang memngakibatkan adanya kerancuan tata hukum dinegara kita, khususnya terkait dengan pencabutan perda oleh lembaga eksekutif ataupun yudikatif. Dalam tataran politik dan hukum adanya dualisme pengujian perda oleh eksekutif (pemerintah cq. Kementrian dalam negeri) dan yudikatif (Mahkamah Agung) akan menimbulkan ketidakpastian hukum dan mengganggu stabilitas politik di daerah. Selain itu adanya kewenangan mencabut perda oleh eksekutive akan menimbulkan persepsi dikalangan ahli hukum ataupun masyarakat bahwa peraturan ini merupakan desentralisasi setengah hati dimana pemerintah pusat masih dapat mengintervensi peraturan yang telah dibuat suatu daerah otonom tanpa menyerahkan kewenangan tersebut pada lembaga yang lebih independen tanpa muatan politik yaitu di lembaga yudikatif (Mahkamah Agung). Oleh karena itu penting bagi penulis unuk mengkaji lebih mendalam tentang lembaga mana yang lebih tepat menerima kewenangan menguji perda terhadap peraturan perundang-undangan yang lebih tinggi. Sehingga penulis mengambil judul ini yaitu "PENGATURAN KEWENANGAN JUDICIAL REVIEW PERDA OLEH MAHKAMAH AGUNG DAN PEMERINTAH" dengan harapan bisa memberikan wacana baru dan sumbangsih terhadap hukum di Indonesia terutama bagi hukum Tata Negara di Indonesia.

\section{Rumusan Masalah}

1. Mengapa Mahkamah Agung dan Pemerintah mempunyai kewenangan yang sama dalam menguji Peraturan Daerah?

2. Apa akibat hukum yang ditimbulkan dengan adanya dua kewenangan pengujian Peraturan Daerah oleh eksekutif review dan judicial review?

3. Bagaimana memberikan batasan terhadap kewenangan pengujian perda menggunakan eksekutif review dan judicial review?

\footnotetext{
${ }^{7}$ Fatmawati, Hak Menguji,( Toetsingrecht), yang dimiliki hakim dalam system hukum Indonesi, Jakarta: Raja Grafindo Persada. hlm 77-78
} 


\section{METODE PENELITIAN}

Jenis penelitian yang digunakan dalam penelitian ini adalah penelitian hukum normatif, yaitu suatu jenis penelitian hukum yang diperoleh dari studi kepustakaan, dengan menganalisis suatu permasalahan hukum melalui peraturan perundang-undangan, literaturliteratur dan bahan-bahan referensi lainnya yang berhubungan dengan pembahasan penelitian dalam Sistem Norma Hukum Negara Republik Indonesia.

\section{Pendekatan Masalah}

a. Pendekatan perundang-undangan (statute approach) dengan tidak melupakan pengungkapan rasio logis lahirnya perundang-undangan khususnya perundangundangan terkait dengan pengujian kewenangan menguji peraturan daerah yang menjadi objek dalam penulisan tesis ini.

b. Pendekatan konseptual (conceptual approach) dengan beranjak dari pandanganpandangan dan doktrin-doktrin yang berkembang dalam ilmu hukum, diantaranya teori otonomi daerah, teori perundang-undangan dan teori pengujian.

\section{Sumber Bahan Hukum}

a. Sumber bahan hukum primer yaitu data yang diperoleh dari norma atau kaidahkaidah dasar yang diperoleh dari Undang-Undang Dasar Negara Republik Indonesia Tahun 1945 dan peraturan perundang-undangan

b. Bahan hukum sekunder yaitu tidak termasuk peraturan-perundang-undangan akan tetapi mempunyai fungsi dalam mempertegas atau menjelaskan bahan hukum primer

c. Bahan hukum tersier yaitu digunakan dalam rangka memberikan wawasan diluar bahan hukum primer dan sekunder yang masih terkait dengan keduanya dan lebih berfungsi sebagai penunjang.

\section{Tehnik Pengumpulan Bahan Hukum}

Pengumpulan bahan hukum dilakukan dengan cara menelaah berbagai referensi kepustakaan yang relevan dengan penelitian yang akan dibahas yaitu literature-literatur, karya ilmiah, peraturan perundang-undangan, majalah, surat kabar, jurnal ilmiah, dokumentasi dari berbagai instansi yang terkait dengan penelitian ini, hal ini dimaksudkan untuk mendapatkan kerangka teori terkait penelitian ini dari hasil pemikiran para ahli kemudian dilihat relevansinya dengan fakta yang ada dilapangan.

\section{Pengolahan Bahan Hukum}

Data yang diperoleh baik bahan primer maupun bahan sekunder dikelompokan kemudian diseleksi, diklarifikasi dan disusun secara sistematis sesuai dengan pokokpokok permasalahan yang diangkat setelah itu diolah untuk mendapatkan bahan hukum yang benar.

\section{Analisa Bahan Hukum}


Analisisis bahan hukum yang digunakan adalah analisis kualitatif, yaitu metode analisis bahan dengan cara mendeskripsikan yang diperoleh kedalam bentuk kalimatkalimat yang terperinci dan jelas, dengan menggunakan cara berpikir deduktif dan induktif. Metode deduktif adalah kerangka berpikir dengan cara menarik kesimpulan dari bahan-bahan yang bersifat umum kedalam bahan yang bersifat khusus dan dengan metode induktif adalah kerangka berpikir dengan cara menarik kesimpulan dari bahanbahan yang bersifat khusus kedalam bahan yang bersifat umum.

\section{PENGATURAN MAHKAMAH AGUNG DAN PEMERINTAH DALAM MENGUJI PERATURAN DAERAH}

\section{Pembatalan Peraturan Daerah oleh Mahkamah Agung}

Wewenang Mahkamah Agung sebagai lembaga yang melakukan kekuasaan kehakiman diberi kewenangan oleh UUDNRI tahun 1945 untuk melakukan pengujian peraturan perundang-undangan di bawah undang-undang terhadap undang-undang kewenangan demikian ini kemudian dikenal dengan istilah judicial review atau pengujian peraturan perundang-undangan oleh lembaga kehakiman. Bila dikaitkan dengan jenis dan hirarki peraturan Perundang-undangan yang diatur dalam pasal 7 Undang-Undang No 10 Tahun 2004 tentang Pembentukan peraturan Perundang-undangan, maka Mahkamah Agung memiliki kewenangan menguji terhadap:

a. Peraturan Pemerintah.

b. Peraturan Presiden.

c. Peraturan Daerah.

Wewenag Mahkamah Agung dalam rangka pembatalan Perda diatur dalam UUD NRI Tahun 1945 dan Undang-undang. Peraturan tentang Mahkamah Agung tersebut diatur di dalam :

Pasal 24A Ayat (1) UUD 1945 menyatakan : " Mahkamah Agung Berwenang mengadili pada tinggkat kasasi, menguji peraturan perundang-undangan dibawah Undang-undang di bawah Undang-undang terhadap Undang-undang, dan mempunyai wewengang lainnya yang diberikan oleh Undang-undang. Pasal 11 ayat (2) huruf b dan ayat (3) Undang-undang Nomor 4 Tahun 2004 tentang kekuasan Kehakiman. Ketentuan Pasal 11 ayat (2) huruf b menyatakan : " menguji peraturan perundang-undangan di bawah Undang-undang terhadap Undang-undang. Ketentuan pasal 11 ayat (3) menyatakan : Pernyataan tidak berlaku peraturan perundang-undangan sebagai hasil pengujian sebagaimana dimaksud pada ayat (2) huruf $b$, dapat diambil baik dalam pemeriksaan tingkat kasasi maupun berdasarkan permohonan langsung kepada Mahkamah Agung. Pasal 31 dan 31A Undangundang Nomor 14 Tahun 1985 tentang Mahkamah Agung, sebagaimana telah berubah dua kali terakhir dengan Undang-undang Nomor 3 tahun 2009. Ketentuan Pasal 31 Undangundang Nomor 14 Tahun 1985 menyatakan: Mahkamah Agung mempunyai wewenang menguji secara materiil hanya terhadap peraturan perundang-undangan di bawah ini Undang-undang. Mahkamah Agung berwenang menyatakan tidak sah semua peraturan perundang-undangan atas alasan bertentangan dengan peraturan-undangan yang lebih 
tinggi atau pembentukannya tidak memenuhi ketentuan yang berlaku. Putusan tentang pernyataan tidak sahnya peraturan perundang-undangan sebagaimana yang di maksud ayat (2) dapat diambil berhubungan dengan pemeriksaan dalam tingkat kasasi. Peraturan perundangan yang dinyatakan tidak sah sebagaimana dimaksud pada ayat (3) tidak mempunyai kekuatan hukum mengikat. Untuk melaksanakan kewenangan pengujian peraturan perundang undangan, Mahkamah Agung telah menerbitkan Peraturan Mahkamah Agung Nomor 1 Tahun 1999, tentang Hak Uji Materiil yang dinyatakan tidak berlaku dan digantikan dengan Peraturan Mahkamah Agung Nomor 1 Tahun 2004, tentang Hak Uji Materiil. Peraturan Mahkamah Agung Nomor 1 Tahun 2004 mempersempit kewenangan pengujian oleh Mahkamah Agung yang oleh UUD dan undang-undang diberi kewenangan menguji materiil dan formil peraturan perundang-undangan, menjadi hanya melakukan pengujian materiil terhadap materi muatan peraturan perundang-undangan. Hal ini berarti Mahkamah Agung tidak memeriksa atau menguji aspek formil penyusunan dan pembentukan peraturan perundang-undangan di bawah undang-undang. Kondisi demikian terkesan bertindak di luar kewenangan, yakni membatasi kewenangan sendiri yang juga merupakan bagian dari kewajiban hukum dan kepastian hukum itu sendiri.

\section{Pembatalan Perda oleh pemerintah}

Pengujian Perda oleh Pemerintah atau yang dalam kajian pengujian peraturan (toetzingrecht) dikenal dengan istilah executive review lahir dari kewenangan pengawasan Pemerintah Pusat terhadap penyelenggaraan (otonomi) Pemerintahan Daerah. Dalam rangka pengawasan terhadap daerah, UU No. 32 Tahun 2004 yang diperbaharui dengan UU No 23 Tahun 2014 memberi perintah bahwa Perda yang dibuat oleh DPRD bersama Kepala Daerah agar disampaikan kepada Pemerintah paling lama 7 (tujuh) hari setelah ditetapkan. Terkait dengan pembatalan Perda, Pasal 136 Ayat (4) UUNo. 32 Tahun 2004 yang diperbaharui dengan UU No 23 Tahun 2014 menyebutkan bahwa "Perda dilarang bertentangan dengan kepentingan umum dan/atau peraturan perundang-undangan yang lebih tinggi." Kemudian Pasal 145 ayat (2) UU tersebut menyebutkan "Perda yang bertentangan dengan kepentingan umum dan/atau peraturan perundang-undangan yang lebih tinggi dapat dibatalkan oleh pemerintah." Ayat (3) menyebutkan "Keputusan pembatalan Perda ditetapkan dengan Peraturan Presiden paling lama 60 (enam puluh) hari sejak diterimanya Perda..." selanjutnya Ayat (5) menyebutkan "Apabila provinsi/kabupaten/kota tidak dapat menerima keputusan pembatalan Perda dengan alasan yang dapat dibenarkan oleh peraturan perundangundangan, kepala daerah dapat mengajukan keberatan kepada Mahkamah Agung."

\section{AKIBAT HUKUM YANG DITIMBULKAN DENGAN ADANYA DUA KEWENANGAN PENGUJIAN PERDA OLEH MAHKAMAH AGUNG DAN PEMERINTAH}

Ekses dari peraturan perundang-undangan yang lebih tinggi dijadikan tolak ukur dalam prosedur executive review terhadap pembatalan perda ternyata menimbulkan ekses yang nampaknya cukup serius dalam penyelenggaraan negara. fungsi pemerintah sebagai 
cabang kekuasaan eksekutif bergeser menjalankan fungsi Mahkamah Agung sebagai salah satu pelaku cabang kekuasaan yudikatif.

Bahwa pembahasan di mulai dengan runtuhnya orde baru yang diwarnai dengan tuntutan-tuntutan mahasiswa. Salah satu tuntutan yang paling utama adalah mengamandemen UUD Tahun 1945. Amandemen UUD Tahun 1945 lebih dilator belakangi dengan kekuasaan eksekutif yang sangat mendominasi dan cenderung membuat siapapun presidennya untuk otoriter dalam menyelenggarakan negara, maka untuk itu hal sangat prinsip dalam amandemen dengan memperkuat sistem check and balances antara lembaga negara. (Majelis Permusyawaratan Rakyat, 2007, Panduan Pemasyarakatan UUD Tahun 1945 Negara Republik Indonesia Sesuai dengan Bab, Pasal dan Ayat, Sekretariat Jenderal MPR RI, hlm. 6-7). Sehingga, latar belakang amandemen UUD Tahun 1945 mengarah kepada penguatan sistem presidensial yang memisahkan cabang kekuasaan dan menganut sistem check and balances. Di anutnya sistem presidensial dapat dilihat pada lima kesepakatan dasar para anggora MPR ketika melakukan amandemen. ${ }^{8}$

Ciri utama dalam sistem presidensial adalah Separation of Power yang mana masingmasing cabang kekuasaan bersifat terpisah dan mandiri. Sedangkan menurut Montesquieu dalam bukunya L'Espirit des Lois 1784, pemisahan kekuasaan tersebut dari cabang kekuasaan legislatif sebagai pembuat undang-undang; cabang kekusaan eksekutif sebagai pelaksana undang-undang; dan yudikatif untuk menghakimi. ${ }^{9}$

Dengan pemberian wewenang Pemerintah Pusat dan Gubernur sebagai wakil dari pemerintah pusat untuk menilai atau menguji apakah suatu perda bertentangan dengan peraturan perundang-undangan yang lebih tinggi, sebagaimana di atur dalam Pasal 251 ayat (1) dan ayat (2) sesungguhnya bentuk inkonsistensi terhadap sistem presidensial yang di anut UUD Tahun 1945. Pemerintah Pusat sebagai cabang kekuasaan eksekutif telah merongrong dan ikut campur urusan rumah tangga cabang kekuasaan yudikatif, yaitu MA sebagai penguji legalitas peraturan perundang-undangan di bawah undang-undang. Artinya, frasa 'Peraturan Perundang-Undangan yang Lebih tinggi' Pasal 251 ayat (1) dan ayat (2) sesungguhnya bertentangan dengan maksud dari ketentuan Pasal 24A ayat (1) UUD Tahun 1945 yang secara konstitusional sebagai satu-satunya lembaga konsitusi yang memiliki kewenangan konstitusional untuk menguji apakah peraturan perundang-undangan di bawah undang-undangan c.q. perda bertentangan dengan undang-undang.

Jika berpegang pada teori lex posteriore derogate lex priore maka seharusnya Pasal 9 ayat (2) Undang-Undang Nomor 12 Tahun 2011 secara otomatis menghapus atau menghilangkan daya guna ketentuan Pasal 145 dan Pasal 185 ayat (5) Undang-Undang Nomor 32 Tahun 2004 tentang Pemerintahan Daerah. Sehingga kewenangan untuk melakukan pengawasan represif

8 Denny Indrayana, Amandemen UUD 1945 Antara Mitos dan Pembongkaran, Bandung: Mizan:, 2007, hlm. 337

9 Jimly Asshiddiqie, Pengantar Ilmu Hukum Tata Negara, Jakarta: Rajawali Pers, 2009, hlm. 282 
terhadap Peraturan Daerah tidak secara absolut dapat dilakukan oleh Pemerintah, melainkan harus melalui Mahkamah Agung. ${ }^{10}$

Jika berpegang pada teori lex specialis derogate lex generalis maka seharusnya ketentuan Pasal 145 dan Pasal 185 ayat (5) di Undang-Undang Nomor 32 Tahun 2004 menjadi tidak berlaku karena Undang-Undang Nomor 32 Tahun 2004 merupakan pengaturan umum tentang pemerintahan daerah yang sebagian kecil di dalamnya memuat aturan tentang pembentukan peraturan perundang-undangan yang secara khusus di atur kemudian di dalam Undang-Undang Nomor 12 Tahun 2011 tentang Pembentukan Peraturan Perundangundangan. ${ }^{11}$

\section{BATASAN TERHADAP KEWENANGAN PENGUJIAN PERDA MENGGUNAKAN EKSEKUTIFE REVIEW DAN JUDICIAL REVIEW}

Undang-Undang Dasar Negara Republik Indonesia Tahun 1945 mengatur hal baru dalam hal kekuasan kehakiman, antara lain pengaturan tentang kewenangan hak judicial review dalam melakukan pengujian UU terhadap UUD dilakukan oleh Mahkamah Konstitusi dan diaturnya kewenangan Mahkamah Agung untuk menguji peraturan perundangundangan dibawah UU terhadap UU. Kekuasaan Kehakiman dalam Undang-Undang Dasar Negara Republik Indonesia

Tahun 1945 diatur dalam Pasal 24, Pasal 24A, Pasal 24B, Pasal 24C.Kewenangan Mahkamah Konstitusi dan Mahkamah Agung dalam melakukan judicial review, selanjutnya diatur dalam Pasal 11 UU Nomor 4 Tahun2004 tentang Kekuasaan Kehakiman, Pasal 31 dan Pasal 31A UU Nomor 5 Tahun2004 tentang Perubahan Atas UU Nomor 14 Tahun 1985 tentang Mahkamah Agung, Pasal 10 UU Nomor 24 Tahun 2003 tentang Mahkamah Konstitusi. Dalam perspektif teori konstitusi dianutnya sistem judicial review, berarti suatu pencapaian tahap akhir konsolidasi konsep negara hukum dimana konstitusi (UUD) diakui sebagai hukum tertinggi yang secara efektif, harus menjadi acuan berdasarkan Pasal 4 Nomor 4 Ketetapan Majelis Permusyawaratan Rakyat Republik Indonesia Nomor I/MPR/2003 tentang Peninjauan Terhadap Materi dan Status Hukum Ketetapan Majelis Permusyawaratan Rakyat Sementara dan Ketetapan Majelis Permusyawaratan Rakyat Republik Indonesia Tahun 1960 sampai dengan Tahun 2002, Ketetapan Majelis Permusyawaratan Rakyat Republik Indonesia Nomor III/MPR/2000 tentang Sumber Hukum dan Tata Urutan Peraturan Perundang-undangan tetap berlaku sampai dengan terbentuknya UU. Saat ini telah ada UU No. 10 Tahun 2004 tentang Pembentukan Peraturan Perundang-undangan yang menggantikan Ketetapan Majelis Permusyawaratan Rakyat Republik Indonesia Nomor III/MPR/2000 tersebut.

Bagi produk-produk hukum yang lebih rendah tingkatannya. Suatu kecenderungan yang bersifat mendasar dalam konstitusionalisme modern adalah konsep konstitusi sebagai kenyataan normatif (normative reality) dan bukan sebagai kompromi politik sesaat dari

10 H.R. Sri Soemantri M. Hak Uji Material di Indonesia, Bandung : Alumni, 1997, hlm. 11.

11 Ibid. 
kelompok-kelompok politik, yang dapat berubah pada setiap saat equilibrium di antara kelompok-kelompok politik itu berubah. berarti konstitusi merupakan perangkat norma hukum yang efektif, yang mengesampingkan proses politik, ekonomi, dan sosial suatu negara dan memberikan keabsahan seluruh tertib hukum. Konsep judicial review atas konstitusionalitas suatu produk UU sesungguhnya merupakan suatu terobosan untuk mencegah berulangnya praktik ketatanegaraan di masa Orde Baru, dimana terjadi konspirasi antara eksekutif (Presiden) dengan legislatif (DPR) yang menghasilkan banyak produk UU yang bertentangan dengan UUD 1945; antara lain UU Pemilu, UU Parpol dan Golkar, UU Organisasi Kemasyarakat-an, UU Pemerintahan Desa dan sebagainya. Konspirasi eksekutif dengan legislatif dilakukan untuk tujuan memperkuat kedudukan pemerintah dengan mengorbankan hak-hak dan kebebasan dasar rakyat yang secara jelas diakui dan dijamin oleh UUD 1945. Konspirasi politik jahat itu dimungkinkan terjadi karena Presiden mengontrol semua fraksi di DPR. Berbagai UU yang menyimpangi UUD 1945 itu telah direvisi. Akan tetapi, perubahan itu tidak melalui proses judicial review, tetapi karena desakan reformasi yang memaksa DPR dan pemerintah merubah berbagai produk UU tersebut. ${ }^{12}$

\section{KESIMPULAN}

Penyebab terjadinya tumpang tindih kewenangan antara Mahkamah Agung dan pemerintah untuk menguji produk hukum Peraturan Daerah yang bertentangan dengan peraturan diatasnya terjadi karena ketidak cermatan pembuat undang-undang dalam menetapkan undang-undang terkait. Secara eksplisit maupun secara implisit yang lebih berwenang secara konstitusi adalah Mahkamah Agung.

Terkait hal tersebut di atas, pemerintah harus lebih jeli dalam membuat perundangundangan agar kedepan tidak menimbulkan kerancuan hukum dalam mengatur tugas-tugas lembaga negara, sehingga lembaga negara bisa bekerja sesuai dengan kewenangannya tanpa ada ketumpang-tindihan dengan lembaga negara lainnya.

12 AR Brewer-Carias sebagaimana dikutip Gurita, Kewenangan "Judicial Review" MPR, Kompas, diakses pada 4 September 2017. 


\section{DAFTAR BACAAN}

Fatmawati, Hak Menguji,( Toetsingrecht), yang Dimiliki Hakim dalam Sistem Hukum Indonesia, Jakarta: Raja Grafindo Persada.

Hadjon, Philipus M., Tentang Wewenang, Dalam buku Iza Rumesten RS, Sinkronisasi Materi Muatan Produk hukum Derah, Palembang: Aulia Cendikia Press, 2009.

Hadjon, Philpus M., dalam buku Victor Imanuel W. Nalle, Konsep Uji Materil: Kajian Pembetukan dan Uji Materil Peraturan Kebijakan di Indonesia, Malang: Setara Press, 2013

Irianto, Bassoence, Negara Hukum dan Hak Konstitusionalitas Mahkamah Konstitusi. Bandung: alumni, 2008.

Iza, Rumesten RS, Sinkronisasi Materi Muatan Produk hukum Derah, Palembang: Aulia Cendikia Press, 2009.

Jimly, Assyiddiqie, Pokok-Pokok Hukum Tata Negara Indonesia Pasca Reformasi, Jakarta: PT.Bhuana Ilmu Populer, 2007.

Mahdi, Imam, Hukum Tata Negara Indonesia, Yogyakarta: Teras, 2011.

Mahfud, MD mengawal arah politik Hukum dari prolegnas sampai judicial review http. www mahfudmd.com/ ublic/makalah makalah_26 pdf diakses 1 April 2017.

Sarjono, Sukanto, I. Pokok-Pokok Sosiologi Hukum. Jakarta: Raja Grafindo Persada. 2012.

Sudikno, Mertokusumo, Bab-Bab Tentang Penemuan Hukum, Jakarta: PT.Citra Aditya Bakti, 1993.

Sudikno, Mertokusumo, Bab-Bab Tentang Penemuan Hukum, Jakarta: PT.Citra Aditya Bakti, 1993. 